\title{
The Impact of the Modern Egyptian City on Egyptian Contemporary Painting: A Comparative Analysis of Five Contemporary Egyptian Models
}

\author{
DOI: $10.21625 /$ archive.v1i1.128 \\ Marwa Mohammed Shazly ${ }^{1}$ \\ ${ }^{1}$ PhD thesis, Faculty of Fine Arts, Helwan University
}

\section{Keywords}

Painting - Contemporary - The City - The Scene - Identity Civilization

\begin{abstract}
Introduction: The view of the outside scene of one of the cities in the painting is an expression mainly used about history and identity. It also expresses the last imagination and prophecy of the future. Not Just an embodiment of the scene in the street or part of a building or a temple in the picture, but it is a reflection of the identity of the people in all its elements.

The search is a selective study of a group of contemporary Egyptian artists who dealt with the theme "landscape" of contemporary photography in Egypt is: Fathi Afifi, Chant Avedissian, Mohamed Abla, Amr Kafrawy and Mona Marzouk.

This paper deals with the impact of the modern Egyptian city of the contemporary Egyptian imaging through following five artists with different ages, educational backgrounds and methods of modern processors and contemporary paintings.
\end{abstract}

Background: Background lies in the presentation of styles of a group of Egyptian artists and contemporary questionnaire handling the modern city in Egypt.

Research problem: The seach of truth about the methods of pictorial handling of the contemporary city or urban landscape covered by the Egyptians contemporary artists.

Research Objectives: The search is keen to throw light on some contemporary methods that deal with the city intellectually, visually and technically through a simple, multi-launch of some of the different models of contemporary painters Egyptians.

Hypotheses: The Egyptian city has a cultural heritage. The reality of life and architectural, and the visual elements created a form of diversification or variety through the contemporary artists artisit of Egyot who are different from the rest of the artists.

The importance of research: The importance of research is giving the opportunity to learn about the impact of the modern Egyptian city on the Egyptian contemporary painting.

Spatial or geographical boundaries of the search: Spatial boundaries are the Arab Republic of Egypt.

Time limits to search: time-lapse is determined to search for the specified term "contemporary history", which extends to one generation, that is, approximately thirtyfive years. 
Undoubtedly, the modern Egyptian city - was affected vitally by the Egyptian contemporary artists, both from artists landscapes or -artists who are not interested in the scenery at the base, and through the research, we find that the real impact stems mainly from social, political and economic changes in the city at a high pace in a few decades. These changes do not affect the scene of the city only, but roll change tempers people of the city and its art. Political, economic and social changes appeared as an impact on the layout of the city and its development, which has produced various filming affected by the previous artists. Fathi Afifi, Chant Avedissian, Mohamed Abla, Mona Marzouk, Amr Kafrawy are a group of Egyptian contemporary artists who have been taking part of their works in this research due to the various qualitiesin terms of style or dealings, technique, cultural and educational background- the way of thinking and age group as well.

\section{Fathi Afifi: Born on 1950}

The city has many faces. One of which is the industrial side of the city, that is the most brutal side. Fathi Afifi shares his vision of the city factories and its relationship with workers via his paintings. In a large group of his paintings, he monitors the relationship he had experience from personal and realistic perspective. He hinged totally on his history of work in the sixties up to the eighties.

Also in his collection "hard workers", we find that Afifi reviewed the simple man's life in a heroic image. It is the image of the struggling man who lives in a cruel city. We see the people of the city who are walking the streets and crossing the road, as we see them in the metro stations of different means of transportation.

Afifi presented in his artistic career, the city's life, people’s lives and workers' lives workers in their factories. Also, other inhabitatns are presented, like the pass byers in the streets and transit roads. He also introduced and dealt with the contemporary art to complicate the relationship between humanbeings and the city. Some critics saw it as a confirmation of being an inherent artist who has not received any techinical or academic education.

Fathi Afifi paints his works on canvas or wood, using black and white oil paints, as he believes that these colours give large graphical card contribute to the delivery of his ideas for the recipient. ${ }^{1}$

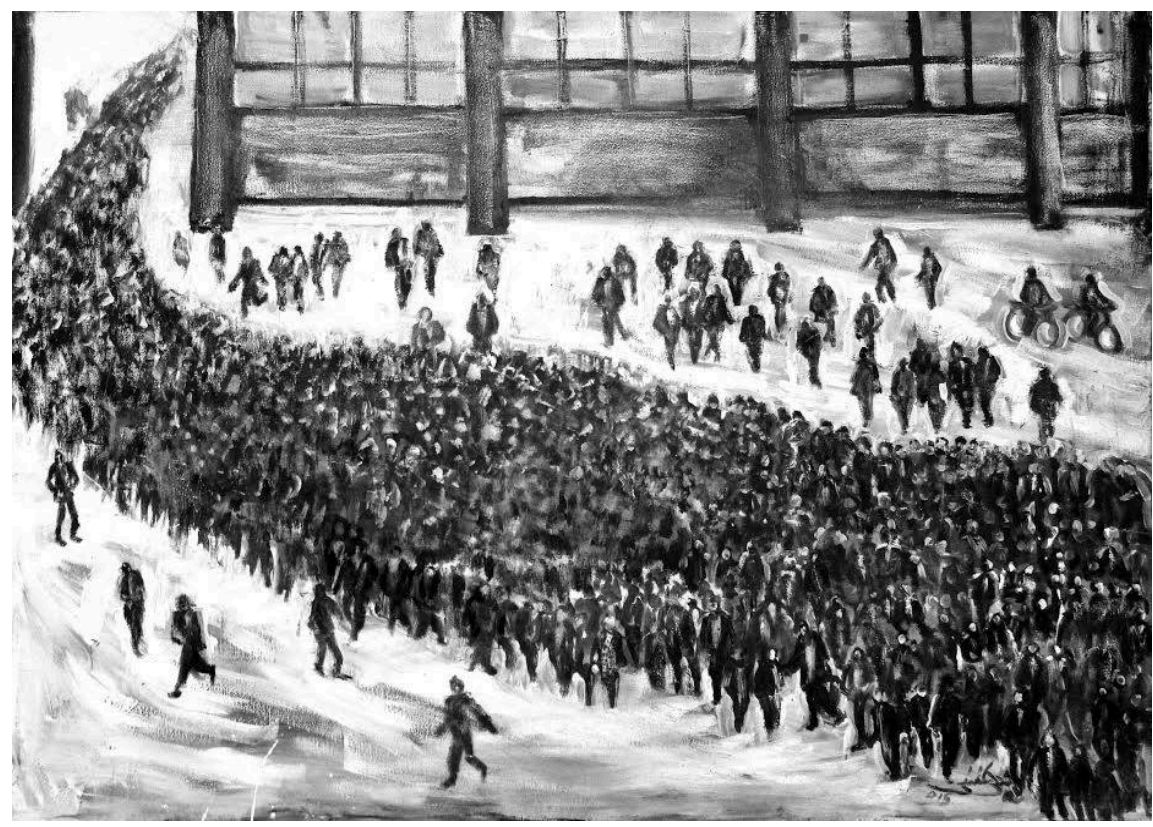

Figure 1.Fathi Afifi: Oil on Canvas, 100 x $70 \mathrm{~cm} 2015$

\section{Chant Avedissian: Born in Cairo on 1951}

Chant studied at Fine Arts, in the city of Montreal, Canada, for a period of three years. It stated from 1970 to 1973 , and then he moved to France and studied at the Higher National College of Art and Decoration for two yearsfrom 1974 to 1976 . Then, he came back to Egypt in 1980 to work with great emotion with the Egyptian architect Hassan Fathi for eight years, since 1981 to $1989^{2}$.

Through Chant educational, cultural background, he became an Orientalist - to some extent. The Egyptian city in his work seemed full of emotion and nostalgia. The Egyptian city and urban landscape of Cairo were translated

\footnotetext{
${ }^{1}$ www.gate.ahram.org.eg/News/608784.aspx.

${ }^{2}$ Rose Issa: Chant Avedissian - Cairo Stencils -, SAQI, London, 2006.
} 
through crowded streets, their acolytes and narrow alleyways of intimacy in Old Cairo. He also had interest in the East or the Pharaonic motifs.

We also find that the state of pride to Chant was coloured with a tinge of sadness on the laps and gone time. We find him attracted to other times of Pharaonic Egypt, painted temples and cities still turned into ruins as what has been done in the town of Qurna in Luxor. He fumble footsteps disappeared, including his campaign of civilization. In other words, the nostalgia and craving are the basis in Chant Avedisaan works.

As for Chant craft style or rather - technique -, we find that Chant greatly capitalized on his studies in France. However, Chant depends in painting his pictures in the style of the stencil and practiced -vs. all its figurative- using warm colors pointing to his city bustling crowd. The city that has provided him with myraids or memories and events.

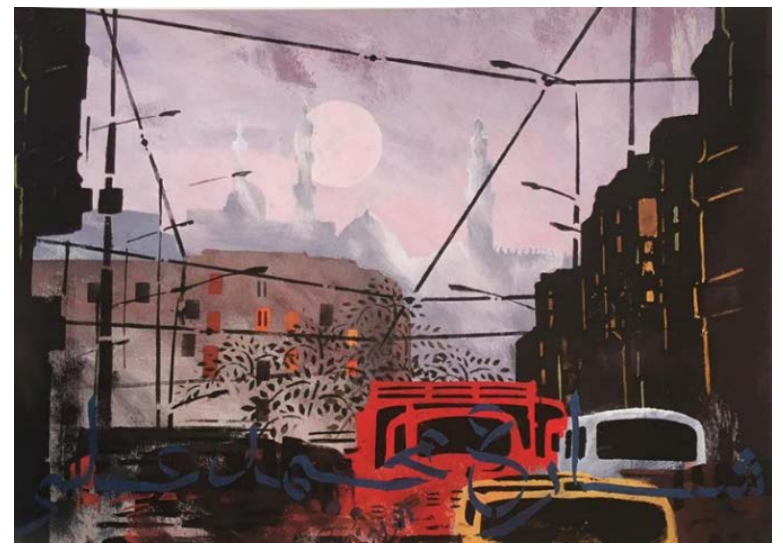

Figure 2 .Chant Avedissian: Mixed medis on paper, $50 \times 70 \mathrm{~cm} 0.1992$ to 1996

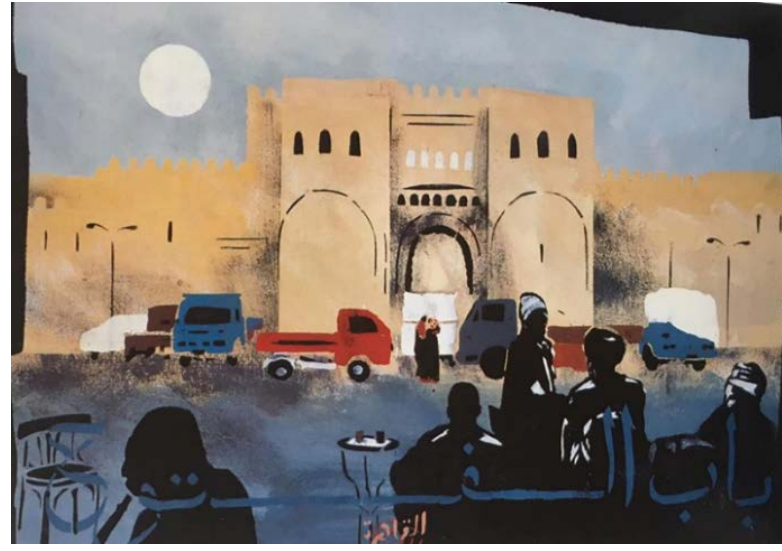

Figure 3.Chant Avedissian: Mixed media on paper 50x70cm, 1992-1996

\title{
Mohamed Abla: Born in Cairo on 1953
}

Abla graduated from the Faculty of Fine Arts - Alexandria University in 1977 and resumed studying art in Switzerland and then in Austria. ${ }^{3}$

Abla turned to read history and if he was looking for the same roots, went to Egypt's oases in the Eastern Desert of being artistic research of historic and humanitarian nature, that study made him realize that the Egyptians culture based mainly on the idea of building and construction, and that they have a clear sense of very land, the place and the environment, all We made them capable of a different civilization, industry, and make them celebrate the urban scene. ${ }^{4}$

\begin{abstract}
Abla says:
"Egypt's problem now is the disappearance of the middle class from the scene, impact, to express themselves. The rich are not interested in building, and the poor can't afford it, and the middle class is the only one capable of building. Doing so destroys the means and futre of culture".

What occupies ABLA in his city is its people who care so much about the city stories that are being narrated. So, Abla draws its great Nile with sailing boats and evenings on shores. Inspite he was from Alexandria in the first place the topic of the Nile has come into force strongly through the summoning of memories of childhood. Such notion is stemmed from his experience when he was observing boatmen come from southern Egypt on their boats with their skinny bodies dancing in continuous movement- that affected his visual imagination. Also, the trip to Luxor, where he spent two months close to the tombs of the western mainland with its Pharaonic drawings that, has left its impact on his work so far. The Nile and the people captured the issues that are very close to his path of art.
\end{abstract}

-Abla depicts his oil color on canvas or Mono print technique on paper.

\footnotetext{
${ }^{3}$ Marwa Mohammed Shazly: contemporary painting in the Middle East and political variables surrounding the impact on the work of the researcher (comparative analysis), PhD thesis, Faculty of Fine Arts, Helwan University .2015

${ }^{4}$ www.art.fenon.com/mohamed-abla/
} 


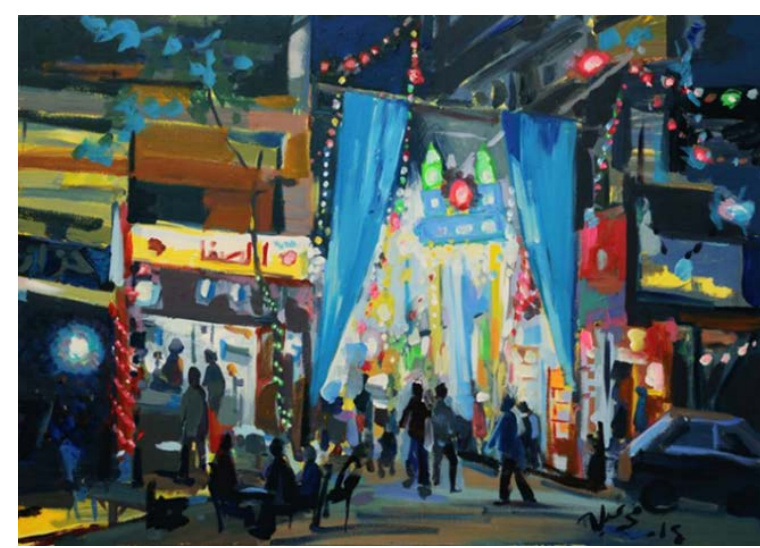

Figure 4. Mohamed Abla: Oil Painting on Canvas, 100 x $70 \mathrm{~cm} 2015$

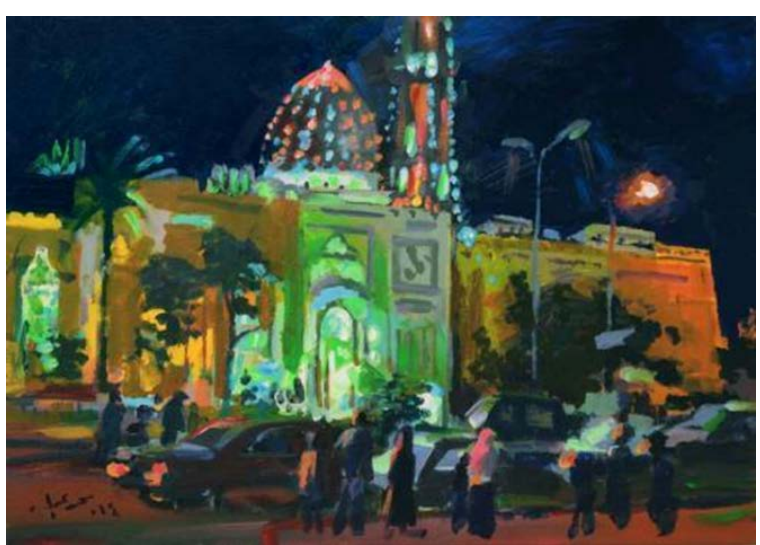

Figure 5. Mohamed Abla: Oil Painting on Canvas, 100 x 70 cm 2015

\section{Mona Marzouk: Born in Alexandria on 1968}

Marzouk got a chance to study at the Dusseldorf Academy in Germany. The academy at the time enjoyed a good reputation in the eighties - with professors such as Joseph Beuys, Jannis Connelas, and Viet June Paik. ${ }^{5}$

The practice and the methodology of Mona Marzouk had architectrd a unique strategy, not only because it involves a long process of research and planning, but also because of her work that is focused on aesthetic virtual systems and standards. It is the discipline that is consistent with the fact that the artist is open to many influences or materials that stimulate his imagination.

We find that Marzouk's paintings have perfectly smooth surfaces, fixed solid colors, and are carefully selected. There is no room to chance in its implementation. As you can see that sculpture painting's relationship is a complementary relationship, they feed each other. Marzouk has a lot of passion about the history and architectural details as he tries to explore the ins and outs and the plans of those dates and details in the space on the wall. In doing so, he creates a different relationship to the science of architecture. It hings on saturated colors. ${ }^{6}$

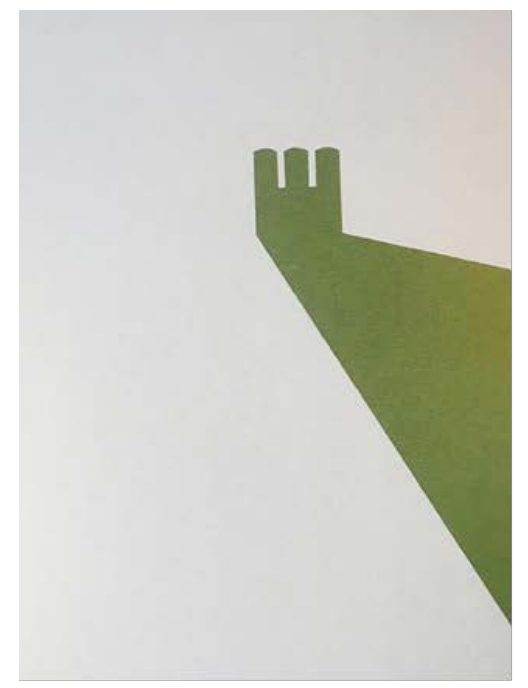

Figure 6. Mona Marzouq: Untitled, Acrylic on Canvas, 60 x 45 x 10 cm, 1999

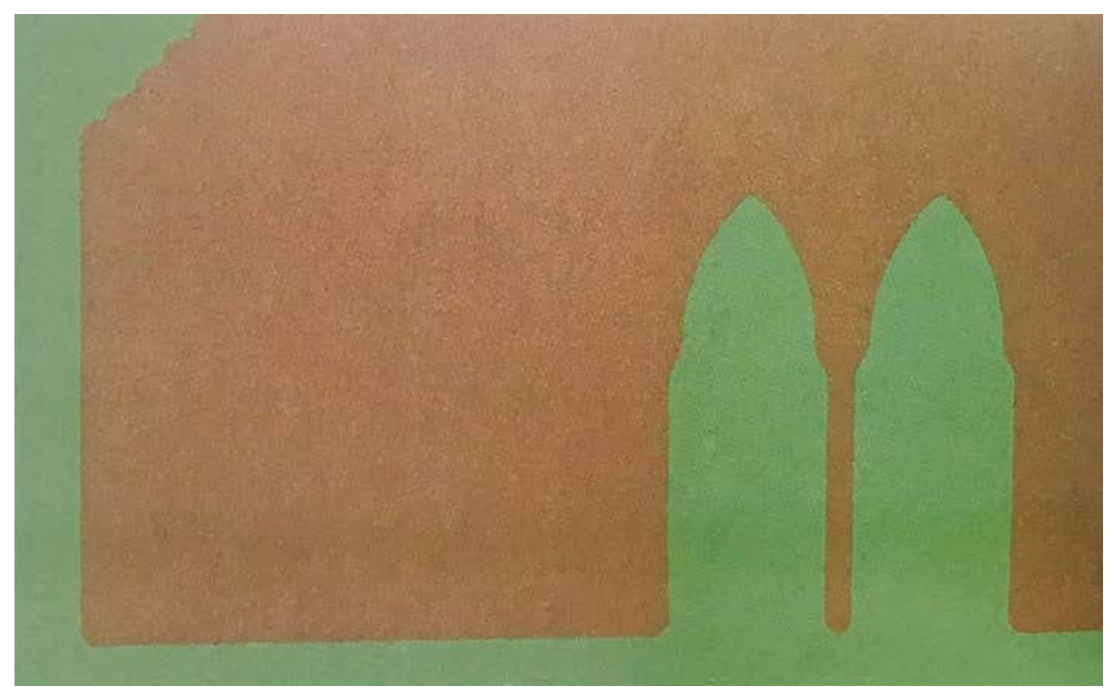

Figure 7. Mona Marzouq: Untitled, Acrylic on Canvas, 27 x 42 x 5 cm, 2001

\footnotetext{
${ }^{5}$ Marwa Mohammed Shazly: contemporary painting in the Middle East and political variables surrounding the impact on the work of the researcher (comparative analysis), PhD thesis, Faculty of Fine Arts, Helwan University .2015

${ }^{6}$ Object Study Mona Marzouk in conversation with Aleya Hamza Ibraaz, Contemporary Visual Culture in North Africa and the Middle East, 6 Nov. 2013
} 


\section{Amr El Kafrawy: Born on 1980}

Kafrawy studied photography at the Faculty of Fine Arts in Cairo for five years.

To Amr Kafrawy, Blur City played an important role where Kafrawy had contradictory feelings toward Cairo, teetering between anger and fear. It creates plates located in the gray distance. The city comes to Kafrawy in a spectacular view, semiconductor buildings, dilapidated buildings, and the explosion that has energised the fear enermously.

The urban landscape of Cairo - from the standpoint of Kafrawy - is a great spectacle, which is reeling from the last act of weights under the weight of inheritance, evidenced by multiple selections carefully chosen- at the same time - of what he drew.

Speaking about his style or technique, we find that Kafrawy tended to the color fading to calculate the gray, we find that the colored "poison" - he said, and he put it - is a way to present and show the gray tones at the expense of the degree of the color strength. His works and his paintings are also executed on recycled paper. It is believed that the raw material is only an equivalent to the logic of his worn city

The importance of research grants the opportunity to learn about the impact of the modern Egyptian city on the Egyptian contemporary painting. ${ }^{7}$

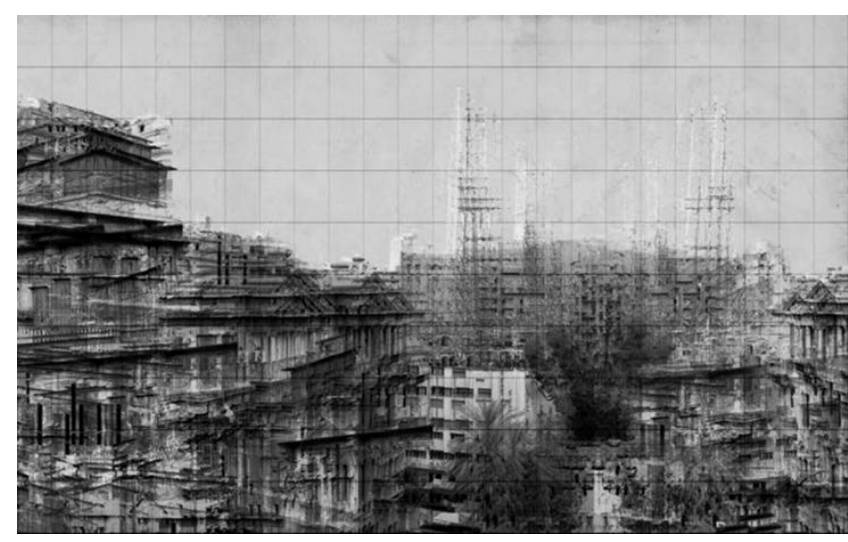

Figure 8. Amr Kafrawy: Printing and drawing on recycled paper, $220 \times 100 \mathrm{~cm}, 2012$

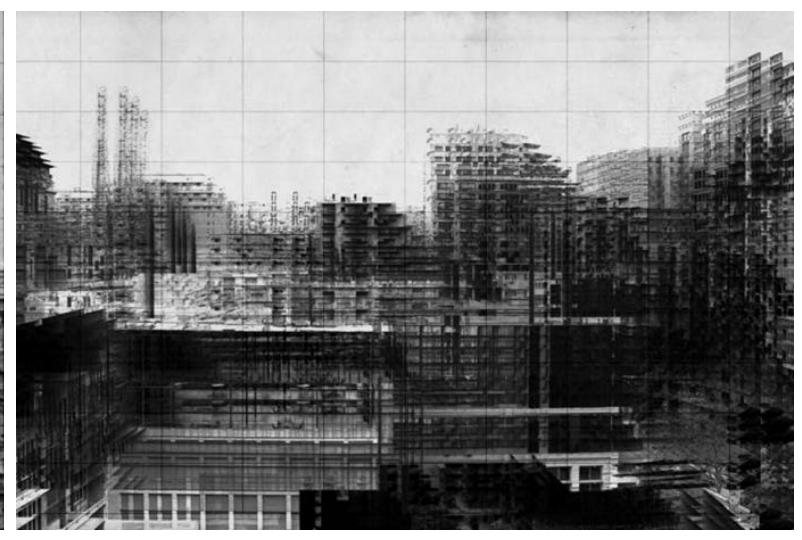

Figure 9. Amr Kafrawy: Printing and drawing on recycled paper, 220 x $100 \mathrm{~cm} 2012$

Analyizing the forementioned points briefly, they reveal the differences between contemporary various artworks of the artists. It also reveals the various forms influenced by artists of the modern Egyptian city:

Fathi Afifi who -is the oldest in the group -comes from simple educational background. He does not belong to any institution or technical Academy; however, he was able through his hardworking and talent to turn his intense realism as a worker in a factory to the technical inter graphic designer carrying attributes of the Egyptian city and its impact on the hard worker Egyptian men.

While Chant Avedissian works are rich of feelings, emotions and nostalgia for the city's golden age came in the fifties and sixties. of this centuries. His paintings reflect Nostalgic joy to a great extent.

We find Abla, the Alexandrian artist in the same age of Fathi Afifi and Chant Avedissian, as bearing the expertise of the Academy, joining his artistic experience loaded with emotions and feelings toward the elements of his home city - Alexandria . it was noticed as closely related to his paintings of the Sea and the Nile, and the stories of humanity, or human beings lived in those areas of the city.

Mona Marzouk, her study abroad experience affected her relationship with the Egyptian city. Sometimes her treatment loaded orientalism with a stinky odor. Mona Marzouk dealt with civilization, Islamic architecture and Egyptian identity from her personal perspective to a large extent. The city of Mona Marzouk was executed in the mentality of architecture, which added to its graphic tinge more excitement.

In nutshell, we find that the city of Kafrawy is only the city of blurry carrying the energies of contradictory and fear. It's the old man of his city who tries hard to postpone the last breath. It is a city in which he lived and his generation who has faced many economic, political and social frustrations. It is a generation believing in the culture of rejection which is shown harshly in their work.

\footnotetext{
${ }^{7}$ A personal interview conducted by a researcher with the artist Amr Kafrawi in his studio in Cairo in January 2017
} 


\section{References:}

1. Chadli, M. M. (2015). Contemporary painting in the Middle East and political variables surrounding the impact on the work of the researcher (comparative analysis)(Unpublished doctoral dissertation). Faculty of Fine Arts, Helwan .

2. Vitamin D2: New Perspectives in Drawing. (2012). Phaidon.

3. Karnouk, L. (2005). Modern Egyptian Art: 1910-2003. AUC Press.

4. Issa, R. (2006). Chant Avedissian - Cairo Stencils . London: SAQI.

5. Hamza, A. (2013, November 6). Object Study - Mona Marzouk in conversation with Aleya Hamza. Retrieved August 30, 2017, from http://www.ibraaz.org/interviews/108

6. TAMASS (2004), Contemporary Arab Representation, UNIA, Arteleku, Ms, European Cultural Foundation

7. Pro Helvetia Cairo. (n.d.). Retrieved August 30, 2017, from https://prohelvetia.org.eg/en/

8. Ibrahim, S. (2013, March 13). بالصــور.. التشـكيلى فتحى عفيفى عن معرضــهـ "الكادحون": أنتمى لهذه الفئة و العامل البسـبط بطل معارضي. Retrieved August 30, 2017, from http://gate.ahram.org.eg/News/608784.aspx 